\author{
Roman ULBRICH ${ }^{1}$ \\ Marcin KARAŚ ${ }^{2}$ \\ Daniel ZAJAC ${ }^{3}$
}

\title{
WYMIANA CIEPŁA I WIZUALIZACJA PRZEPLYWU DWUFAZOWEGO W PRZESTRZENI MIĘDZYRUROWEJ
}

\begin{abstract}
W pracy zaprezentowano wyniki badań nad wizualizacją przepływu dwufazowego poprzecznego do modelowego pęku rur. Do realizacji założonego celu wykorzystano m.in. metodę cyfrowej anemometrii obrazowej DPIV. Badania przeprowadzono dla dwóch układów pęku rur - szeregowego i przestawnego, przy zróżnicowanych strumieniach fazy ciekłej i gazowej, w zakresie odpowiednio 800-1200 i $10-60 \mathrm{dm}^{3} / \mathrm{h}$. Rezultatami badań były pola prędkości fazy ciekłej, identyfikacja pojawiających się struktur przepływu oraz wielkości powierzchni stref. Rezultaty wizualizacji zestawiono z wynikami badań wymiany ciepła podczas przepływu dwufazowego przez przestawny i równoległy pęk rur. Do pomiarów wykorzystano metodę elektrochemiczną opartą na analogii wymiany ciepła i masy. Otrzymane wyniki pozwoliły na analizę wpływu hydrodynamiki przepływu na intensywność wymiany ciepła na powierzchni rur w pęku.
\end{abstract}

Słowa kluczowe: analogia Chiltona-Colburna, DPIV, metoda elektrochemiczna, wnikanie masy

\section{Wstęp}

Przepływ poprzeczny do pęku rur występuje w wymiennikach płaszczowo-rurowych z zamontowanymi przegrodami. Rozwiązanie to stosuje się, gdy współczynnik wnikania ciepła płynu po stronie międzyrurowej jest znacznie mniejszy w porównaniu z czynnikiem przepływającym wewnątrz rur. Przegrody ustawione prostopadle do osi wzdłużnej wymiennika zmniejszają pole przekroju przestrzeni międzyrurowej oraz zmieniają kierunek przepływu płynu poprzecznie do pęku rurek. Rezultatem jest zwiększenie prędkości i burzliwości strugi przepływającego płynu, co prowadzi do intensyfikacji wnikania ciepła.

\footnotetext{
${ }^{1}$ Autor do korespondencji/corresponding author: Roman Ulbrich, Politechnika Opolska, ul. S. Mikołajczyka 5, 45-271 Opole, tel.: (77) 4498390, e-mail r.ulbrich@ po.opole.pl.

${ }^{2}$ Marcin Karaś, GEA Technika Cieplna Sp. z o.o., e-mail marcin.karas@gea.com.

${ }^{3}$ Daniel Zając, Politechnika Opolska, e-mail d.zajac@po.opole.pl.
} 
Przepływy dwufazowe gaz-ciecz występują w wymiennikach płaszczowo-rurowych, najczęściej w procesach, w trakcie których dochodzi do przemiany fazowej. Wymienniki tego typu są używane jako kotły, generatory pary, chłodnice czy rekuperatory. Stosowane są też w połączeniu z kolumnami barbotażowymi, z których podczas reakcji chemicznej należy odebrać ciepło lub je tam dostarczyć. Proces wrzenia, podczas którego występuje przepływ dwufazowy, występuje w wielu aparatach przemysłowych, takich jak wyparki, warniki czy parowniki zalane. Wrzenie pojawia się także w parownikach chłodziarek absorpcyjnych, wykorzystywanych w układach poligeneracyjnych, jednocześnie wytwarzających energię cieplną, elektryczną oraz dodatkowo chłód, otrzymywany dzięki chłodziarce. W zależności od wielkości strumieni doprowadzanych faz, ich właściwości fizykochemicznych i(lub) parametrów wrzenia formują się różne struktury przepływu. Duża liczba nowo wydawanych publikacji z tego zakresu pokazuje, że badania przepływu dwufazowego są wciąż w kręgu zainteresowań badaczy [2-4]. Jest to również spowodowane faktem, że pomimo wielu badań nad strukturami przepływu dwufazowego ich charakter nie został jeszcze w pełni poznany.

\section{Stanowisko badawcze i metodyka badań}

Głównym elementem stanowiska doświadczalnego, na którym wykonano badania, były dwa układy pęków rur wykonane z pleksiglasu (każdy z pięcioma rzędami rur). W pierwszym $\mathrm{z}$ nich układ rurek był szeregowy, w drugim przestawny. Pęk rur wykonano z przezroczystych walców o długości $60 \mathrm{~mm}$, średnicy $15 \mathrm{~mm}$ i podziałce $t / d=1,66$. Schemat stanowiska badawczego zaprezentowano na rys. 1. Przez pęk rur przepływała mieszanina dwufazowa gaz-ciecz. Poszczególne serie pomiarowe różniły się strumieniami przepływu faz ciekłej i gazowej w zakresie odpowiednio $800-1200 \mathrm{oraz} 10-60 \mathrm{dm}^{3} / \mathrm{h}$. Do przepływającego płynu dodawano poliamidowe cząstki znacznikowe o średnicy $20 \mu \mathrm{m}$. Obszar przepływu oświetlano laserem ciągłym o mocy $1 \mathrm{~W}$, wytwarzającym wiązkę światła o długości fali $\lambda=532 \mathrm{~nm}$. Oświetlony obszar przepływu rejestrowano kamerą CMOS o rozdzielczości 1024x1024 pikseli i częstotliwości rejestracji $462 \mathrm{~Hz}$. Do pomiaru natężenia prądu zastosowano układ elektrod niklowych. Elektrody zanurzono w wodnym roztworze potasu. Anoda w postaci niklowanej siatki znajdowała się przy wypływie elektrolitu z wymiennika, a jako katodę zastosowano niklowane blaszki miedziane osadzone na obwodzie rurki, którą można zastąpić dowolną rurkę w pęku. Zastosowany układ elektryczny pozwalał na dostarczenie określonego, skokowo rosnącego i stabilizowanego napięcia prądu stałego, płynącego przez roztwór elektrolitu pomiędzy katodą i anodą.

Do badań metodą elektrochemiczną zastosowano układ elektrod niklowych zanurzonych w roztworze mieszaniny heksacyjanożelazinu i heksacyjanożelazianu potasu: $\mathrm{K}_{3} \mathrm{Fe}(\mathrm{CN})_{6}$ i $\mathrm{K}_{4} \mathrm{Fe}(\mathrm{CN})_{6}$. Koncepcja badań opierała się na pomiarze wartości natężenia prądu płynącego przez katodę umieszczoną na po- 
wierzchni rurki przy wzroście napięcia prądu przyłożonego do układu. Zmierzone wartości posłużyły do wyznaczenia krzywych polaryzacyjnych, dzięki którym ustalono wartości prądu granicznego plateau potrzebne do określenia współczynnika wnikania masy $[1,6]$. Następnie zastosowano analogię wymiany masy i ciepła Chiltona-Colburna oraz wyznaczono wartości współczynnika wnikania ciepła, co pozwoliło na określenie intensywności wymiany ciepła na powierzchni rurek.

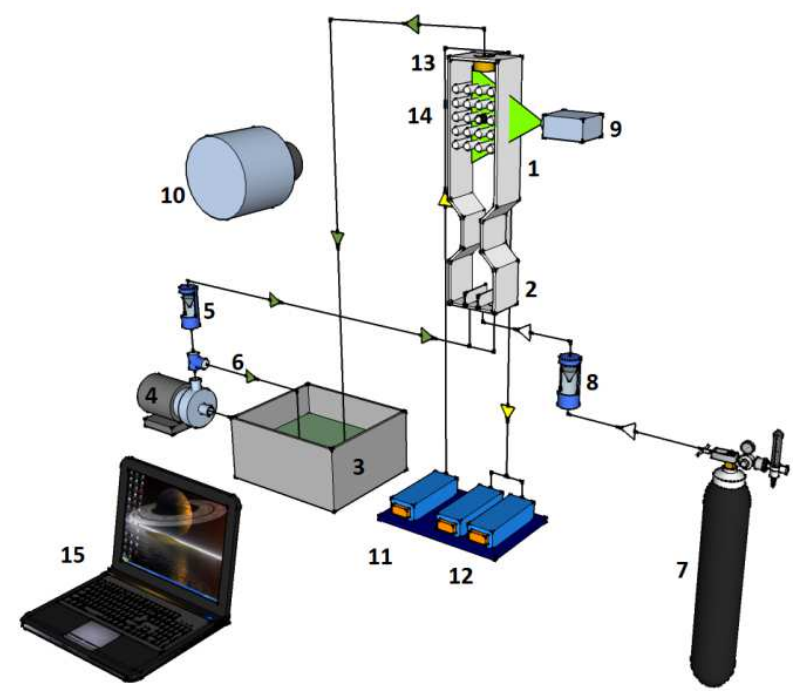

Rys. 1. Schemat stanowiska badawczego; 1 - model pęku rur, 2 - komora mieszania faz, 3 - naczynie zbiorcze, 4 - pompa, 5 - rotametr, 6 - bypass, 7 - butla $\mathrm{z}$ azotem, 8 - rotametr, 9 - laser, 10 - kamera cyfrowa, 11, 12 - układ rejestrująco-sterujący napięciem i prądem elektrycznym, 13 - anoda, 14 - katoda

Fig. 1. Schematic of measuring position; $1-$ tube bundle model, 2 - mixing chamber, 3 - expansion vessel, 4 - pump, 5 - rotameter, 6 - bypass, 7 - nitrogen tank, 8 - rotameter, 9 - laser, 10 - digital camera, 11, 12 - capture-control system for current and voltage, 13 - anode, 14 - cathode

Pomiary pól prędkości metodą DPIV polegały na rejestracji obrazów przepływu z wysoką częstotliwością, które następnie poddawano cyfrowemu przetwarzaniu i analizie obrazu [5]. Celem było uzyskanie informacji o zmianach charakterystyki przepływu w przypadku różnych strumieni faz oraz porównanie wyników dla dwóch układów pęku rur. Obrazy rejestrowano dla obszaru wokół pojedynczych rur umieszczonych w trzecim rzędzie w pęku. 


\section{Analiza wyników badań}

Analiza zarejestrowanych pól prędkości dostarczyła informacji na temat nierównomierności przepływu mieszaniny dwufazowej w pęku rur w zależności od układu pęku i wartości strumieni poszczególnych faz. Wykresy pól prędkości umożliwiają identyfikację obszarów stagnacji występujących za rurami oraz określenie ich wielkości. Na podstawie analizy przemieszczenia znaczników oraz pęcherzy gazu można ocenić zmiany kierunku i prędkości przepływu. Można więc z ich wykorzystaniem scharakteryzować strukturę przepływu dwufazowego w przestrzeni międzyrurowej. Możliwa jest również ocena wpływu układu pęku rur i prędkości przepływu w przestrzeni międzyrurowej na jednorodność pola prędkości oraz ocenę nierównomierności przepływu mieszaniny dwufazowej w pęku rur (rys. 2.). Pola prędkości dla przepływu wokół szeregowego pęku rur charakteryzują się wyraźnym zróżnicowaniem na obszary o wysokiej prędkości pomiędzy rurami oraz obszary, gdzie prędkość jest znacznie niższa, występujące ponad rurami i poniżej nich.

a)

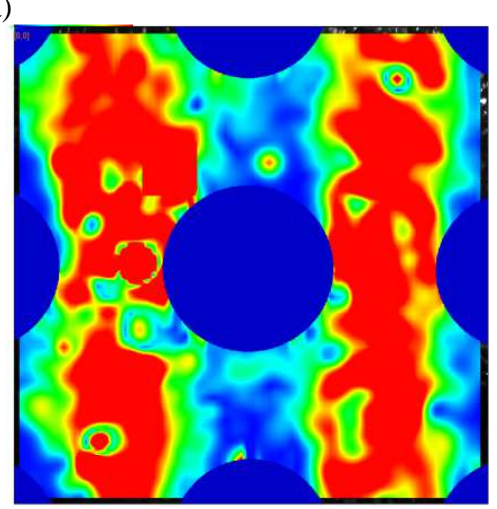

b)

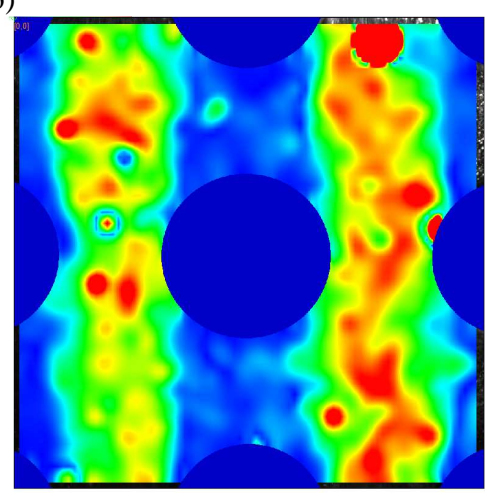

prędkość $[\mathrm{m} / \mathrm{s}]$ 0,2

Rys. 2. Przykład zarejestrowanych pól prędkości dla wybranych strumieni cieczy i gazu: a) $80 \mathrm{dm}^{3} / \mathrm{h}, 60 \mathrm{dm}^{3} / \mathrm{h}$, b) $100 \mathrm{dm}^{3} / \mathrm{h}, 10 \mathrm{dm}^{3} / \mathrm{h}$

Fig. 2. Example of the velocity fields for selected flow rates of liquid and gas: a) $80 \mathrm{dm}^{3} / \mathrm{h}, 60 \mathrm{dm}^{3} / \mathrm{h}$, b) $100 \mathrm{dm}^{3} / \mathrm{h}, 10 \mathrm{dm}^{3} / \mathrm{h}$

W przypadku szeregowego pęku rur pęcherze mogą się unosić swobodnie ku górze, nie napotykając na swojej drodze żadnych przeszkód. To powoduje, że średnia prędkość dla badanego obszaru jest wyższa niż w układzie przestawnym, lecz styk samych rur z obszarami, gdzie prędkość jest wysoka, odbywa się tylko po bokach rur. Analizując wektorowe pola prędkości, można określić trajektorię przepływu mieszaniny dwufazowej. W przypadku układu szeregowego wyraźnie widać obszary pomiędzy rurami, gdzie występuje przepływ wznoszący, niezabu- 
rzony przeszkodami. Czasami jednak występują wektory skierowane w dół lub ku bokom obszaru badawczego. Pokazuje to, że mimo niezmiennej geometrii układu i ustalonych warunków przepływu przepływ dwufazowy jest nierównomierny. Nierównomierność ta wzrastała wraz z rosnącym strumieniem fazy gazowej. Dla wyższych strumieni gazu zaobserwowano bardziej wyraźny podział pomiędzy strefami stagnacji a obszarami przepływu wznoszącego. Również w tych przypadkach częściej obserwowano przepływ w kierunku innym niż wznoszący.

Pola prędkości dla przepływu w przestawnym pęku rur charakteryzują się mniejszym zróżnicowaniem na obszary o wysokiej prędkości pomiędzy rurami oraz takie, gdzie prędkość jest znacznie niższa w porównaniu z szeregowym pękiem rur. Unoszące się pęcherze napotykają na swej drodze rurki, przez co prędkość ich wznoszenia maleje. Rozkład prędkości jest jednak równomierny i zmniejszają się strefy stagnacji. To powoduje, że średnia prędkość dla badanego obszaru jest niższa niż w układzie szeregowym, lecz styk samych rur z obszarami stagnacji występuje tylko za rurkami. Na podstawie wyników badań metodą DPIV analizie poddano również strefy stagnacji, będące cechą charakterystyczną przepływu w pęku rur. Występują one bezpośrednio za rurkami, przy czym prędkość przepływu jest w nich znacznie niższa niż w pozostałych obszarach. Wizualizacja przepływu dwufazowego w przestrzeni międzyrurowej umożliwiła wyznaczenie powierzchni stref stagnacji występujących za rurkami. Zaobserwowano wyraźny spadek wielkości stref stagnacji wraz ze wzrostem strumienia przepływającego gazu. Przy wzroście strumienia cieczy zjawisko to nie było już tak wyraźne. Stwierdzono również, że powierzchnia stref stagnacji jest nieregularna i jej kształt zmienia się dynamicznie. Prowadząc pomiary metodą elektrochemiczną, rejestrowano poziom natężenia prądu, przy którym można było uzyskać tzw. prąd plateau. Przykład uzyskanej krzywej polaryzacyjnej zaprezentowano na rys. 3.

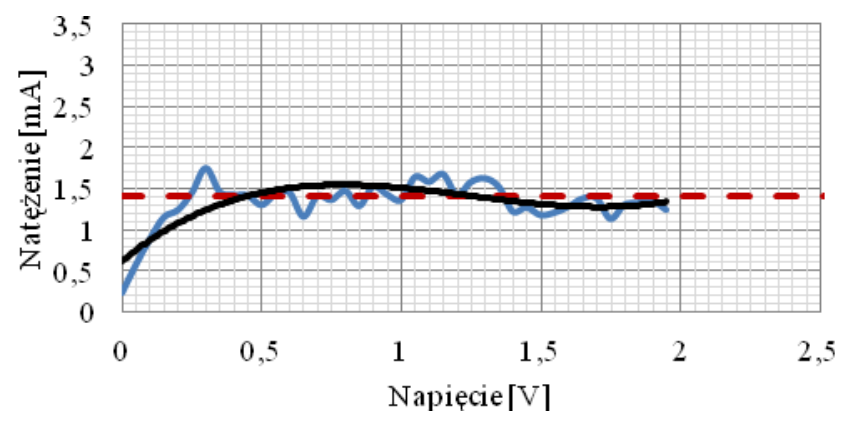

Rys. 3. Przykładowa krzywa polaryzacyjna

Fig. 3. Exemplary polarization curve 
Nie uzyskano idealnie gładkiego odcinka prądu plateau. Wartości wahały się w granicach $\pm 0,5 \mathrm{~mA}$. Można to tłumaczyć bardzo burzliwym charakterem przepływu dwufazowego. W tej części badań głównym celem było przedstawienie nierównomierności intensywności wymiany ciepła na powierzchni rurki umieszczonej w pęku rur. W tym celu przedstawiono rozkład lokalnej liczby Nusselta wyliczonej dla każdej katody umieszczonej na zewnętrznej powierzchni rurek. Wartości te obliczono, wykorzystując analogię Chiltona-Colburna pomiędzy procesami wymiany ciepła i masy.

Średnia wartość liczby Nusselta dla pęku rur o liczbie rzędów <10 jest inna niż w przypadku pęku rur z liczbą rzędów $>10$. Przepływ dla pierwszych rzędów rur nie jest jeszcze w pełni rozwinięty. Wartość liczby Nusselta mierzona na powierzchni rury w pęku zależy od liczby poprzedzających ją rur. Wartość ta wzrasta od 1. rzędu do ok. 5., po czym pozostaje stała. Na podstawie wykresów rozkładu lokalnych wartości liczb Nusselta będących bezwymiarowym odpowiednikiem współczynnika wnikania ciepła dokonano oceny wymiany ciepła na powierzchni modelowych pęków rur wymiennika ciepła (rys. 4.). Można zatem stwierdzić, że zastosowana metoda elektrochemiczna może być z powodzeniem wykorzystywana do badań wymienników ciepła w warunkach przepływu dwufazowego.

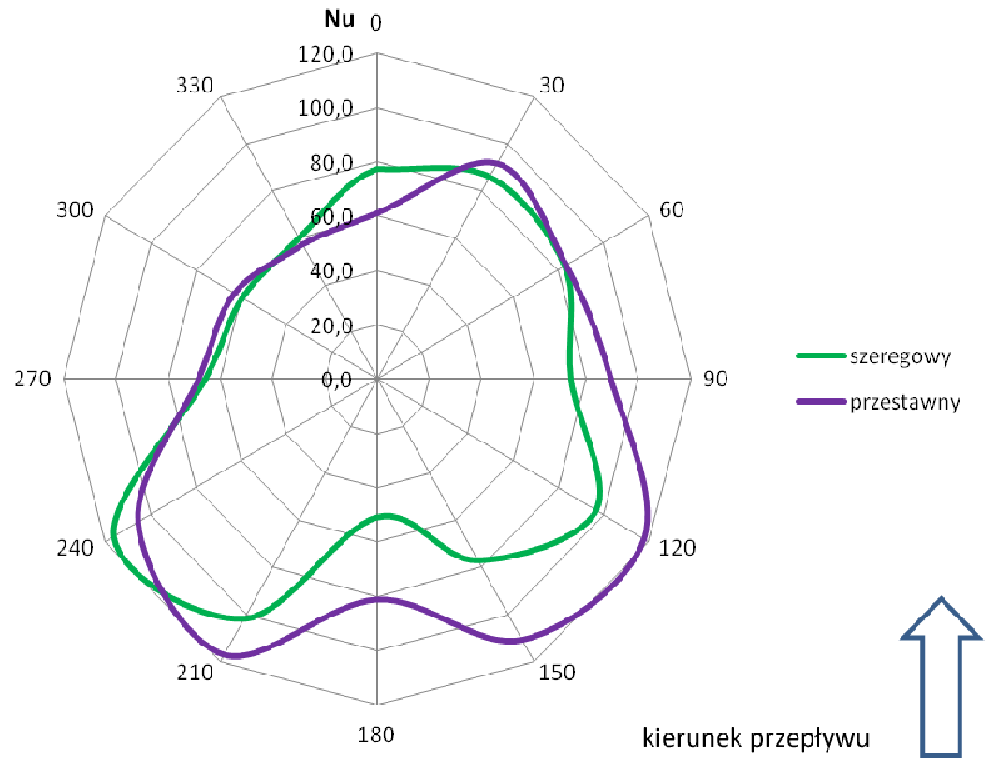

Rys. 4. Uśrednione dla wszystkich strumieni wartości liczby Nusselta dla układów rur szeregowego i przestawnego

Fig. 4. Averaged Nusselt numbers for all flow rates and for inline and staggered tube bundle 
W czołowej części rur, w okolicach 135 i $225^{\circ}$, gdzie strumień mieszaniny dwufazowej rozbijał się o jej powierzchnię, lokalne wartości liczb Nusselta przybierały największe wartości. Zależność tę zaobserwowano dla wszystkich pomiarów i dla obydwu pęków rur. W przypadku pęku przestawnego nierównomierność ta była mniejsza niż w przypadku pęku szeregowego.

\section{Podsumowanie}

Pola prędkości dla obszaru wokół pojedynczych rur wykazują duże podobieństwo charakteru przepływu dla wszystkich wartości strumieni. Zaobserwowano różne struktury: wirowe, pojedyncze, w parach, symetryczne i niesymetryczne. Cechą charakterystyczną przepływu w pęku rur są strefy stagnacji występujące bezpośrednio za rurkami. W strefach tych prędkość przepływu jest znacznie niższa niż w pozostałych obszarach. Wizualizacja przepływu dwufazowego w przestrzeni międzyrurowej umożliwiła ocenę powierzchni stref stagnacji występujących za rurkami. Na podstawie porównania udziałów objętościowych stref stagnacji można dokonać oceny niejednorodności przepływu w zależności od udziałów objętościowych poszczególnych faz. Podczas badań zaobserwowano, że strefy te miały znacznie większą powierzchnię w przypadku szeregowego pęku rur, a największe różnice zaobserwowano dla wyższych wartości strumieni przepływu oraz $\mathrm{w}$ obszarach położonych przed rurkami. Zaobserwowano spadek wielkości stref stagnacji wraz ze wzrostem strumienia przepływającego gazu. Przy wzroście strumienia cieczy zjawisko to nie było już tak wyraźne. Stwierdzono też, że powierzchnia stref stagnacji jest nieregularna i jej kształt zmienia się dynamicznie. Zastosowanie techniki DPIV oraz zarejestrowane za jej pomocą pola prędkości przepływu pozwoliły na ocenę jednorodności rozkładu prędkości i jej zmianę przy różnych parametrach przepływu dla dwóch rodzajów układu pęków rur. Pęk rur szeregowy charakteryzował się znacznie większą nierównomiernością $\mathrm{w}$ porównaniu z przestawnym. Pęcherze wznoszące się pomiędzy rurami nie napotykały na żadne przeszkody, przez co osiągały wyższe prędkości przepływu. W przypadku układu przestawnego średnie i maksymalne prędkości były wyraźnie niższe.

Wyniki pomiarów wymiany ciepła pokazały, że przy przepływie dwufazowym geometria układu pęku rur zastosowanego do budowy wymiennika ciepła ma znaczący wpływ na intensywność wymiany ciepła. Porównując wyniki wszystkich pomiarów dla układów szeregowego i przestawnego przy tym samym stosunku $t / d=1,66$, określono, że układ przestawny jest o ok. $9 \%$ bardziej wydajny niż układ szeregowy. Tworzące się struktury przepływu, w tym przede wszystkim wznoszące się pęcherze, które zaburzają pole prędkości, mają znaczący wpływ na proces wymiany masy i ciepła w modelowym pęku rur. Zauważono duży wpływ zmiany strumienia fazy gazowej na wartości liczb Nusselta. Wyniki obliczeń pokazują, że nawet obecność niewielkiego strumienia fazy gazowej ma duży wpływ na intensywność wymiany ciepła. Nie można zatem 
upraszczać metod obliczeniowych doboru wymienników ciepła i stosować modeli obliczeń jednofazowych dla układów, w których występują dwie fazy.

\title{
Literatura
}

[1] Bieniasz B.: Short ducts consisting of cylindrical segments and their connective mass/heat transfer, pressure drop and performance analysis., Int. J. Heat Mass Transfer, 41 (1998), 501-511.

[2] Dominguez-Ontiveros E.E., Hassan Y.A.: Non-intrusive experimental investigation of flow behavior inside a $5 \times 5$ rod bundle with spacer grids using PIV and MIR, Nuclear Eng. Design, 239 (2009), 888-898.

[3] Iwaki C., Cheong K.H., Monji H., Matsui G.: Vertical, bubbly cross-flow characterristics over tube bundles, Experiments Fluids, 39 (2005), 1024-1039.

[4] Olinto C.R., Indrusiak M.L.S., Endres L.A.M., Moller S.V.: Experimental study of the characteristics of the flow in the first rows of tube banks, Nuclear Eng. Design, 239 (2009), 2022-2034.

[5] Raffel M., Willert Ch.E., Kompenhans J.: Particle image Velocimetry: a Practice Guide, Springer, Berlin 1998.

[6] Wilk J.: Experimental investigation of convective mass/heat transfer in short mini channel at low Reynolds numbers, Exp. Thermal Fluid Sci., 33 (2009), 267-272.

\section{HEAT TRANSFER AND VISUALIZATION OF TWO-PHASE FLOW IN THE TUBE BUNDLE}

\begin{abstract}
S u m m a r y
The paper presents results of research on visualization of two-phase flow across tube bundle models. The method of digital imaging anemometry DPIV was used. The research was carried out for the staggered and in-line tube bundles. The results of the study were the velocity fields of the liquid phase, identification of emerging structures of the flow and the size of the surface areas of stagnation. Results of visualization were compared to the results of research on the conditions of heat transfer during the two-phase flow through in-line and staggered tube bundle. To determine the intensity of heat transfer on the surface of the tube bundle, electrochemical method based on an analogy of heat and mass transfer was used. Obtained results allowed to analyze the impact of hydrodynamic properties on the intensity of heat transfer on the surface of the tubes in a bundle.
\end{abstract}

Keywords: Chilton-Colburn analogy, DPIV, electrochemical method, mass penetration

DOI: $10.7862 / \mathrm{rm} .2015 .26$

Otrzymano/received: $14.09 .2014 \mathrm{r}$.

Zaakceptowano/accepted: 20.03.2015 r. 